\title{
TRTaKadeмi
}

ISSN 2149-9446 | Volume 06 | Issue 13 | September 2021 | Artificial Intelligence

\section{Artificial Intelligence in Communication Studies: An Investigation on Studies Between 1982-2021}

\author{
Hikmet TOSYALI*
}

\begin{abstract}
This study explores the profile of media and communication studies on artificial intelligence and presents a perspective on the general structure of the literature. In this study, 459 scientific studies published between 1982 and 2021, which have been increasing even further since 2016, were examined via bibliometric data. The country that published the most was the USA with $25.1 \%$. Turkey ranked 28 th among 54 countries with four publications. Two hundred sixty-seven article publications were distributed in 96 different journals. By testing the compatibility of this distribution with Bradford's Law, eight core journals meeting the needs of communication literature on artificial intelligence, were identified. New Media \& Society ranked first on this list. Topics covered in the studies focused on journalism, natural language processing, human-robot interaction, social media bots, public relations and advertising. The most frequently used concepts in abstracts and keywords were "automated journalism," "computational journalism," "robot journalism," "ethics," "fake news." The most frequently cited journal was Digital Journalism. The half-life value of cited publications was seven years. The results revealed the artificial intelligence trends in communication studies and the general structure of the communication literature. In addition, it is suggested that the results regarding literature obsolescence and core journals would contribute to the creation of subscriptions and journal collections in libraries.
\end{abstract}

Keywords: Artificial Intelligence, Machine Learning, Media, Communication, Bibliometrics

*Dr. Öğr. Üyesi, Maltepe Üniversitesi, Görsel İletişim Tasarımı Bölümü, tosyali.hikmet@gmail.com

Tosyalı, H. (2021). Artificial Intelligence in Communication Studies: An Investigation on Studies Between 1982-2021 . TRT Akademi , 6 (13) , 680-699 . DOI: 10.37679/trta.965966

Research Paper

Recieved: 09.07.2021

Accepted: 13.09.2021 


\title{
TRTaKadeмi
}

\section{Illetişim Çalışmalarında Yapay Zekâ: 1982-2021 Yılları Arasında- ki Çalışmalara Yönelik Bir İnceleme}

\section{Hikmet TOSYALI}

\begin{abstract}
Öz
Bu çalışmada, yapay zekâyı konu alan medya ve iletişim çalışmalarının profilini keşfetmek ve konuyla ilgili literatürün genel yapısına ilişkin bir perspektif sunmak amaçlanmıştr. Araştırmada, 1982 ile 2021 yılları arasında yayımlanan 459 bilimsel çalışma bibliyometrik veriler ile incelenmiştir. 2016 yılından itibaren çalışmaların sayısı her yıl artmaktadır. En çok yayın yapan ülke \%25,1 ile Amerika Birleşik Devletleri'dir. Türkiye dört yayın ile 54 ülke arasında 28. sıradadır. Makale türündeki 267 yayın 96 farklı dergiye dağılmaktadır. Bu dağılımın Bradford Yasası'na uygunluğu test edilerek yapay zekâ konusunda iletişim literatürünün ihtiyacını karşılayan sekiz çekirdek dergi tespit edilmiştir. New Media \& Society birinci sıradadır. Çalışmalarda ele alınan konular gazetecilik, doğal dil işleme, insan-robot etkileşimi, sosyal medya botları, halkla ilişkiler ve reklamcılık konularında yoğunlaşmaktadır. Özet metinlerde ve anahtar kelimelerde en sık kullanılan kavramlar, "otomatik gazetecilik", "hesaplamalı gazetecilik", "robot gazetecilik", "etik", "yalan haber" şeklindedir. Digital Journalism, en sık atı yapılan dergidir. Atıf yapılan yayınların yarı yaşam değeri yedi yıldır. Elde edilen sonuçlar, iletişim çalışmalarındaki yapay zekâ trendlerini ve iletişim literatürünün genel yapısını ortaya koymaktadır. Ayrıca literatür eskimesi ve çekirdek dergilere ilişkin ulaşılan sonuçların, kütüphanelerde aboneliklerin ve dergi koleksiyonlarının oluşturulmasına katkı sağlayacağı değerlendirilmektedir.
\end{abstract}

Anahtar Kelimeler: Yapay Zekâ, Makine Öğrenmesi, Medya, Iletişim, Bibliyometri 


\section{Introduction}

Technological developments have brought about remarkable changes in many individual and social areas, especially in communication practices. The idea that changing communication practices should be examined and reinterpreted with methodologies suitable for the information age conveys academia to the necessity of a new paradigm. It can be said that one of the essential components of this paradigm may be data. Artificial intelligence technologies (e.g., machine learning, natural language processing, deep learning) used in the collection, processing, storage and sharing of large datasets, the amount of which is increasing due to digital applications, especially the Internet and social media, contribute to the development of computational social sciences by bringing the fields of communication and engineering closer together.

Artificial intelligence, one of the most important components of Industry 4.0 defining the use of robots and automation in production, has gradually increased in the production and sharing of content in the media. Today, in artificial intelligence studies, researchers focus on machines that can also receive feedback in the communication process between humans and machines (or algorithms). This is because, in interpersonal communication, feedback could be vital for human-machine interaction, allowing the parties to see the effects on each other and organize the communication accordingly. The feedback provided by the users while communicating with machines foster the learning process of the machines and enables the artificial intelligence to make further successful decisions every time than the previous one. Therefore, it is possible to say that large datasets on human feedback could accelerate image/sound recognition and natural language processing studies in artificial intelligence.

Journalism and advertising are among the areas where these studies are primarily carried out. Especially in areas dominated by digital data, robot journalists who collect large amounts of data and compile them into a story or share breaking news such as earthquakes, weather conditions, and exchange rates have become prevalent (Caswell \& Dörr, 2018; Lee et al., 2017; Schwencke, 2021; Sim \& Shin, 2016; Tosyalı \& Aytekin, 2020). Media planning processes are slowly moving from humans to algorithms through programmatic buying models. The algorithm decides which ad will be shown to whom by observing the user's digital footprints. Algorithms used in social media platforms create flow pages and recommendations that are unique for each user by taking into account their feedback, such as clicks, likes, and even the view duration of a photo (Alaimo \& Kallinikos, 2018; Busch, 2016; McGuigan, 2019; White \& Samuel, 2019). 
As the number of sectoral and academic studies on practice increases, the number of studies to reveal the effects of these practices on individuals and society (especially in legal and ethical contexts) increases as well. In light of these developments, in this study, the following will be explored: What topics are covered in artificial intelligence studies in media and communication? What are the bibliometric features of the studies? What is the distribution of citations in the bibliography of these studies according to scientific journals?

Bibliometrics is used in many disciplines to detect scientific communication tools such as books and journals by using statistical calculations and monitoring their historical changes (Pritchard, 1969, p. 348). In this way, the most effective studies, researchers and journals on a specific subject could be determined, and the future of scientific studies can be orientated. In bibliometric analyses, information such as the distribution of studies on a particular subject by years, institutions and countries, the number of pages, the development of keywords, productive and effective scholars, author and institution collaborations, research topics and the most cited studies are examined (Akay et al., 2020, p. 105; Binbaşığlu, 2020, p. 2831).

Various bibliometric laws evaluate the distribution of articles published on a subject by journals. One of them is Bradford's Law. Bradford studied how the literature on a particular topic was distributed among scientific journals and formulated the law of distribution, which is named after him, in 1948. (Nash-Stewart et al., 2012, p. 135). The most crucial periodical publications in every field of science could be determined through Bradford's Law, which is based on ordering the periodical publications in the relevant literature based on their efficiency. (Gökkurt, 1994, p. 29). According to Bradford's Law, which enables identifying the most influential and important journals, articles published on any subject or discipline must be distributed among journals in certain proportions. In other words, Bradford's Law states that the need for literature on a particular subject is met by a small number of core journals publishing on that subject. Garfield (1980, p. 477) explains this distribution as follows:

If you want to compile a bibliography on any subject, you will find that there is always a small group of core journals that account for a substantial percentage $(1 / 3)$ of the articles on that subject or discipline. Then there is a second larger group of journals that account for another third while a much larger group of journals picks up the last third.

One of the criteria that determine the use and impact of a publication is the number of its citations in other academic studies. The citation analysis studies 
determine which sources are used in the publications on a specific subject (Özel \& Kozak, 2012, p. 717). For this reason, the results obtained from the citation analysis are used to determine the most productive researchers and the most frequently used resources on a subject, as well as to evaluate scientific research, calculate the obsolescence of the relevant literature, and develop library collections accordingly (AI \& Tonta, 2004, p. 21).

In the literature, there are bibliometric studies on artificial intelligence studies in fields such as journalism (Calvo Rubio \& Ufarte Ruiz, 2021), tourism (Binbaşıŏlu, 2020), health (Kocakoç et al., 2021), economy (Akay et al., 2020) and architecture (Özdemir \& Selçuk, 2021). However, no similar study was found for the general field of communication, including citation analysis. Therefore, it is considered that this research can contribute to the field by filling this gap in communication literature. It aims to provide useful information to researchers, guide current practices in the sector, and help libraries develop policies related to communication through the change in the international literature studies over time and reveal current issues.

\section{Method}

In this study, artificial intelligence studies in communication were examined with bibliometric methods. Based on the literature review, it was determined that the first artificial intelligence study in communication was published in 1982. Thus, the study is limited to previous work published between 1982 and 2021 (June).

Scientific publications examined within the scope of the research were collected from the Web of Science Core Collection database. To collect these publications, 301,367 results were scanned using the word "artificial intelligence." The search results were narrowed to 459 by selecting the "communication" option from the Web of Science categories. These 459 scientific publications, which were considered within the scope of media/communication studies, were included in the research. The research sought answers to the following questions:

RQ1. How have artificial intelligence studies in the field of communication changed over the years?

RQ2. What is the distribution of publications according to the number of authors? RQ3. What is the distribution of the studies according to the language of publication? RQ4. What is the distribution of the studies according to the publication type (article, book chapter, proceedings, book review, editorial material, review)? 
RQ5. What is the distribution of article-type publications according to journals? Does the distribution of articles to journals comply with Bradford's Law? (Is there a core journal group that focuses on artificial intelligence articles in the communication field?)

RQ6. Which authors, institutions and countries publish the most?

RQ7. What topics do the publications focus on?RQ8. What are the most frequently used keywords?

RQ9. Which publications are most cited?

RQ10. Which scientific journals are most frequently cited in publications?

During the database generation process for this study, information about 459 scientific publications scanned in Web of Science was transferred to the Microsoft Excel program. Then, the database of the study was created by classifying the publications according to the year, type of publication, journal, author, institution, country, number of citations, keywords, abstracts and scientific journals cited in the publications. The distribution of article-type studies in the journals was examined based on Bradford's Law. Furthermore, the core journals that met the needs of the communication literature on artificial intelligence were determined. The frequency of words in abstracts, and the links between the keywords were used in determining topics covered in the publications. Abstract and keywords of the publications were analyzed in the NVivo program. The links between keywords and publication collaborations between countries were examined through the VOSviewer. The journals in the bibliography of 459 publications were singularized and added to the database in citation analysis, and the most cited journals were determined.

\section{Results}

\subsection{Distribution of Studies by Year, Number of Authors, Publication Language and Publication Type}

The first artificial intelligence study in communication was published in the Journal of Communication in 1982. The distribution of the number of publications by year is shown in Figure 1. 
Figure 1. Distribution of Publications by Years

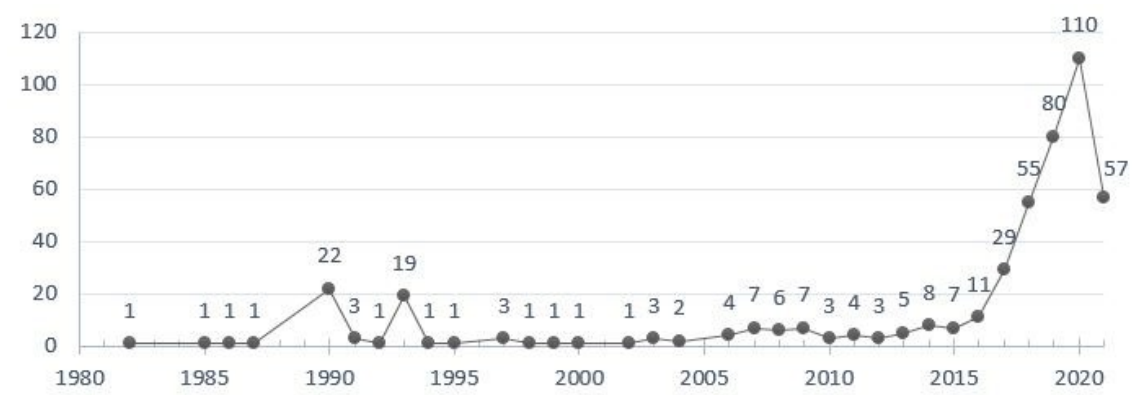

According to Figure 1, the number of artificial intelligence studies in communication has gradually increased every year since 2016. The number of publications in the first half of 2021 was 57 . It can be predicted that by the end of the year, this number will exceed the previous work published in 2020. When the topics of the publications in 2016 and 2017 were examined, studies on chatbots and social media bots became prominent. When the studies published in 1990 and 1993 were examined, it could be seen that the papers presented at the communication congresses on artificial intelligence were held in the USA, the Netherlands and France.

Among the publications, 210 (45.7\%) had one author, 126 (27.4\%) had two authors, 65 (14.2\%) had three authors, and 32 (7\%) had four authors, 26 (5.7\%) had five or more authors. The publication with the most collaboration had 12 authors. 415 publications were written in English, 33 in Spanish, 6 in Russian, 2 in Portuguese, 1 in French, 1 in Italian and 1 in Malay.

The distribution of 459 studies within the scope of the research by publication types is shown in Table 1.

Table 1. Distribution by Publication Types

\begin{tabular}{|l|r|r|}
\hline Publication Type & $\mathbf{n}$ & $\mathbf{\%}$ \\
\hline Article & 267 & 58.2 \\
Proceedings & 106 & 23.1 \\
Book Chapter & 48 & 10.5 \\
Editorial Material & 18 & 3.9 \\
Book Review & 13 & 2.8 \\
Review & 7 & 1.5 \\
\hline Total Publication & 459 & 100.0 \\
\hline
\end{tabular}


According to Table 1, among 459 publications, 267 (58.2\%) were articles, 106 (23.1\%) were papers, 48 (10.5\%) were book chapters, 18 (3.9\%) were editorial materials, 13 (2.8\%) were book reviews, and 7 (1.5\%) were reviews.

\subsection{Distribution of Articles by Journals}

When the distribution of 267 articles in the article type was examined according to the journals, it could be seen that the articles were published in 96 different scientific journals. Conformity of the distribution of the articles to the journals with the Bradford's Law, one of the bibliometric laws, was examined by using the formula proposed by Egghe and Rousseau (1990, pp. 295-296). According to Bradford's Law, one-third of the articles on a topic should be published by a small core journal group. The second group of journals must publish the other third of the articles with a larger number than the previous one. A much larger third group of journals are required to publish the last third of the articles. In summary, Bradford's Law reveals that the need for literature on a particular subject could be met by a small number of core journals publishing on that subject. To understand whether there may be a core group among the communication journals that publish articles on artificial intelligence, the distribution of the articles among the journals was examined according to the Bradford's Law and the results were presented in Table 2.

Table 2. Distribution of Articles to Journals

\begin{tabular}{|c|c|c|c|c|c|c|c|c|}
\hline \multirow[b]{3}{*}{ Group } & \multicolumn{4}{|c|}{$\begin{array}{c}\text { Distribution According to Research } \\
\text { Results }\end{array}$} & \multicolumn{4}{|c|}{ Distribution According to Bradford's Law } \\
\hline & \multicolumn{2}{|c|}{$\begin{array}{r}\text { Number of } \\
\text { Journals }\end{array}$} & \multicolumn{2}{|c|}{ Number of Articles } & \multicolumn{2}{|c|}{$\begin{array}{r}\text { Number of Jour- } \\
\text { nals }\end{array}$} & \multicolumn{2}{|c|}{ Number of Articles } \\
\hline & $n$ & $\%$ & $n$ & $\%$ & $n$ & $\%$ & $n$ & $\%$ \\
\hline 1 & 8 & 8.3 & 90 & 33.7 & 8 & 8.3 & 89 & 33.3 \\
\hline 2 & 20 & 20.8 & 88 & 33.0 & 22 & 22.9 & 89 & 33.3 \\
\hline 3 & 68 & 70.8 & 89 & 33.3 & 66 & 68.8 & 89 & 33.3 \\
\hline Total & 96 & $99.9^{*}$ & 267 & 100.0 & 96 & 100.0 & 267 & $99.9^{*}$ \\
\hline
\end{tabular}

*Totals differ from $100 \%$ due to rounding.

According to Table 2, the distribution of articles to journals complies with Bradford's Law. According to Bradford's Law, the number of core journals in the first group (that is, the highest number of articles in a fewer issue) would be 8 . The number of journals in the second group would be 22 , and the number of journals in the third group that published a small number of articles would be 66 . According to the research data, the number of core journals in the first group was 8 , the number of journals in the second group was 20 , and the number of journals 
in the third group that published a small number of articles was 68 . In other words, $8.3 \%$ of the journals cover $33.7 \%$ of the literature. The eight core journals with the highest number of articles are shown in Table 3.

Table 3. Core Journals with the Most Articles

\begin{tabular}{|r|l|r|r|}
\hline & Journal Name & $n$ & $\%$ \\
\hline 1 & New Media \& Society & 15 & 5.6 \\
2 & Telecommunications Policy & 14 & 5.2 \\
3 & Information, Communication \& Society & 12 & 4.4 \\
4 & Interaction Studies & 11 & 4.1 \\
5 & Profesional de la información & 10 & 3.8 \\
6 & Social Media + Society & 10 & 3.8 \\
7 & Journal of Advertising & 9 & 3.4 \\
8 & Digital Journalism & 9 & 3.4 \\
\hline & Total & 90 & 33.7 \\
\hline
\end{tabular}

According to Table 3, among the eight core journals that published one-third (90 articles) of artificial intelligence articles in communication, New Media \& Society ranked first with 15 articles. Telecommunications Policy ranked second with 14 articles published on the digital economy, data science, and new media. Information, Communication \& Society came third with 12 published articles. Interaction Studies was in fourth place, with 11 published articles focusing on social behavior and communication in biological and artificial systems. The Spanish journals Profesional de la información and Social Media + Society each published 10 articles. Finally, the Journal of Advertising and Digital Journalism each published 9 articles.

\subsection{Top Publishing Authors, Institutions and Countries}

Publications were written by 851 different authors. The most productive authors who contributed to the literature with three or more publications are presented in Table 4.

Table 4. Top Published Authors

\begin{tabular}{|l|r|r|}
\hline Author & $\mathrm{n}$ & $\%$ \\
\hline Togelius, Julian & 12 & 2.6 \\
Montebello, Matthew & 9 & 2 \\
Lewis, Seth C. & 5 & 1.1 \\
Walton, Douglas & 5 & 1.1 \\
Guzman, Andrea L. & 4 & 0.9 \\
Ufarte Ruiz, Maria Jose & 4 & 0.9
\end{tabular}




\begin{tabular}{|l|r|r|} 
Natale, Simone & 4 & 0.9 \\
Feijoo, Claudio & 3 & 0.7 \\
Herrera-Viedma, Enrique & 3 & 0.7 \\
Kietzmann, Jan & 3 & 0.7 \\
Carvalhais, Miguel & 3 & 0.7 \\
Taylor, Richard D. & 3 & 0.7 \\
\hline Total & 3 & 0.7 \\
\hline
\end{tabular}

One author worked in 12 publications, one author in 9 publications, two authors in 5 publications each, three authors in 4 publications, six authors in 3 publications, 43 authors in 2 publications and 795 authors in 1 publication. Julian Togelius was at the top of the list, contributing the most to the literature with 12 studies. Matthew Montebello followed him with nine publications, C. Seth Lewis and Douglas Walton with five publications each. All 13 authors in Table 4 made up $13.1 \%$ of the contributed literature.

When the institutions affiliated in the publications were examined, 454 different universities were identified. The most productive universities contributing to the literature with over five publications are shown in Table 5.

Table 5. Top Publishing Universities

\begin{tabular}{|l|r|r|}
\hline University & $\mathrm{n}$ & $\%$ \\
\hline University of Santiago de Compostela & 9 & 2 \\
University of Malta & 9 & 2 \\
Complutense University of Madrid & 8 & 1.7 \\
Penn State University & 7 & 1.5 \\
Michigan State University & 6 & 1.3 \\
University of Oregon & 6 & 1.3 \\
Northern Illinois University & 6 & 1.3 \\
University of Windsor & 6 & 1.3 \\
University of Seville & 6 & 1.3 \\
University of Amsterdam & 6 & 1.3 \\
Universidad de Castilla-La Mancha & 6 & 1.3 \\
\hline Total & 75 & 16.3 \\
\hline
\end{tabular}

Universities in Table 5 were affiliated in 75 (16.3\%) of 459 publications. At the top of the list were the University of Santiago de Compostela and the University of Malta, with 9 studies each. 4 of these universities are located in Spain, 4 in the USA, 
1 in the Netherlands, 1 in Canada, and 1 in Malta. In 16.3\% of the publications in the literature, 11 universities in the list were affiliated Having examined the distribution of publications by country, it was seen that 54 different countries contributed to 459 studies. The top 10 countries with the most publications are shown in Table 6.

Table 6. Top 10 Countries with the Most Publications

\begin{tabular}{|l|r|r|}
\hline Country & $\mathrm{n}$ & $\%$ \\
\hline USA & 115 & 25.1 \\
Spain & 63 & 13.7 \\
England & 35 & 7.6 \\
Germany & 28 & 6.1 \\
Netherlands & 28 & 6.1 \\
China & 23 & 5 \\
Canada & 23 & 5 \\
Italy & 13 & 2.8 \\
Australia & 13 & 2.8 \\
Russia & 10 & 2.2 \\
\hline Total & 351 & 76.5 \\
\hline
\end{tabular}

According to Table 6, out of 351 publications, the USA contributed the most to the field, with 115 publications (25.1\%). The total percentage of publications made in 10 countries constituted $76.5 \%$ of the literature. Spain is in second place with 63 publications and England is in third place with 35 publications. Turkey ranked 28th among 54 countries with 4 publications. The map of international collaboration established between countries is shown in Figure 2.

Figure 2. International Collaboration Map

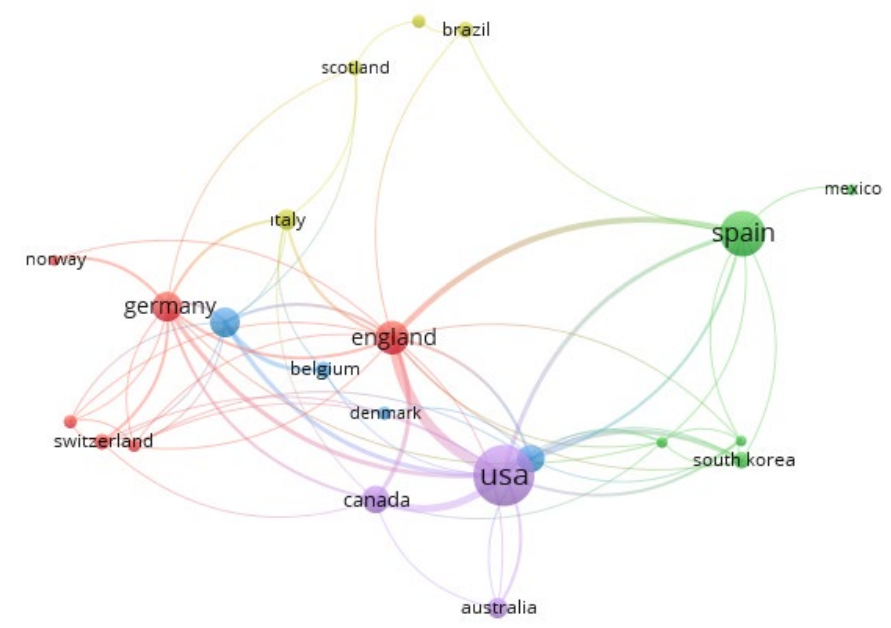


According to Figure 2, international collaboration was established between 22 countries. England occupies a central position, with $22.9 \%$ of partnerships established between England and 16 other countries. England was followed by the USA, Germany, the Netherlands, China and Spain. According to the number of publications, the closest collaborations were held between the USA and the following countries: England, Canada, Germany, Spain, the Netherlands and South Korea, respectively.

\subsection{Topics Covered in Publications and Most Frequently Used Keywords}

The frequency of the words in abstracts of the publications and the links between the keywords were used to examine the topics covered in the publications. Initially, the frequency of the words in abstracts and the most frequently used keywords were determined (see Figure 3). Then, a keyword map was created in VOSviewer to determine the connections among the most frequently used keywords (see Figure 4).

Figure 3. Most Frequently Used Words in Abstracts and Keywords
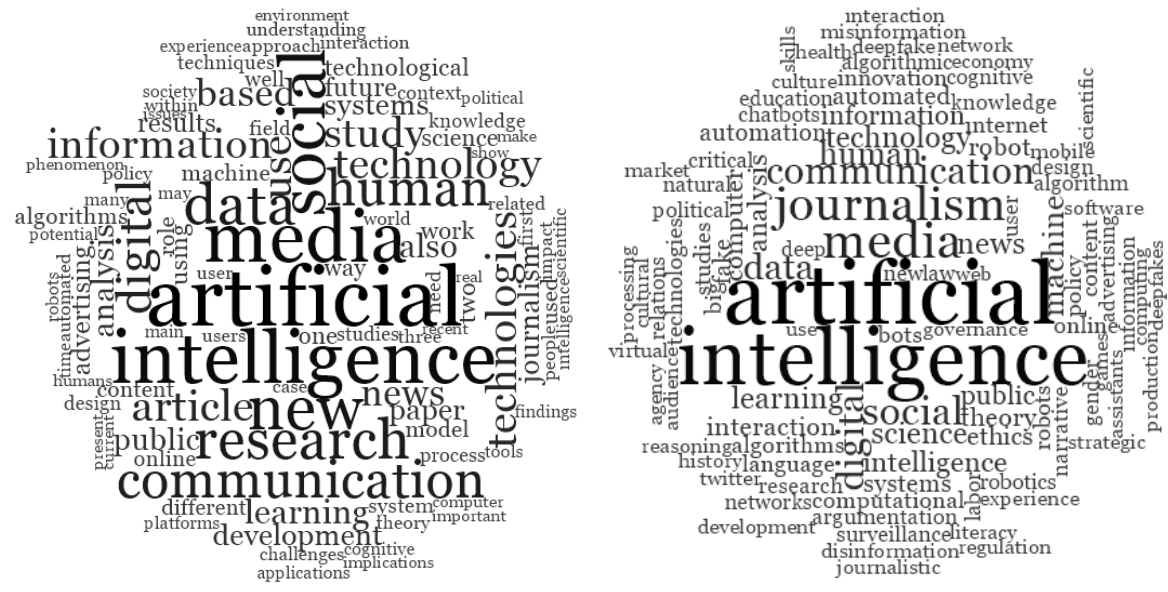

In Figure 3, the most frequently used words in abstracts are on the left, and the most frequently used keywords are on the right. In both word clouds, "artificial intelligence," "media," "journalism," "communication," "data," "news," "digital," and "information" were the most frequently used words. 
Figure 4. Keyword Link Map

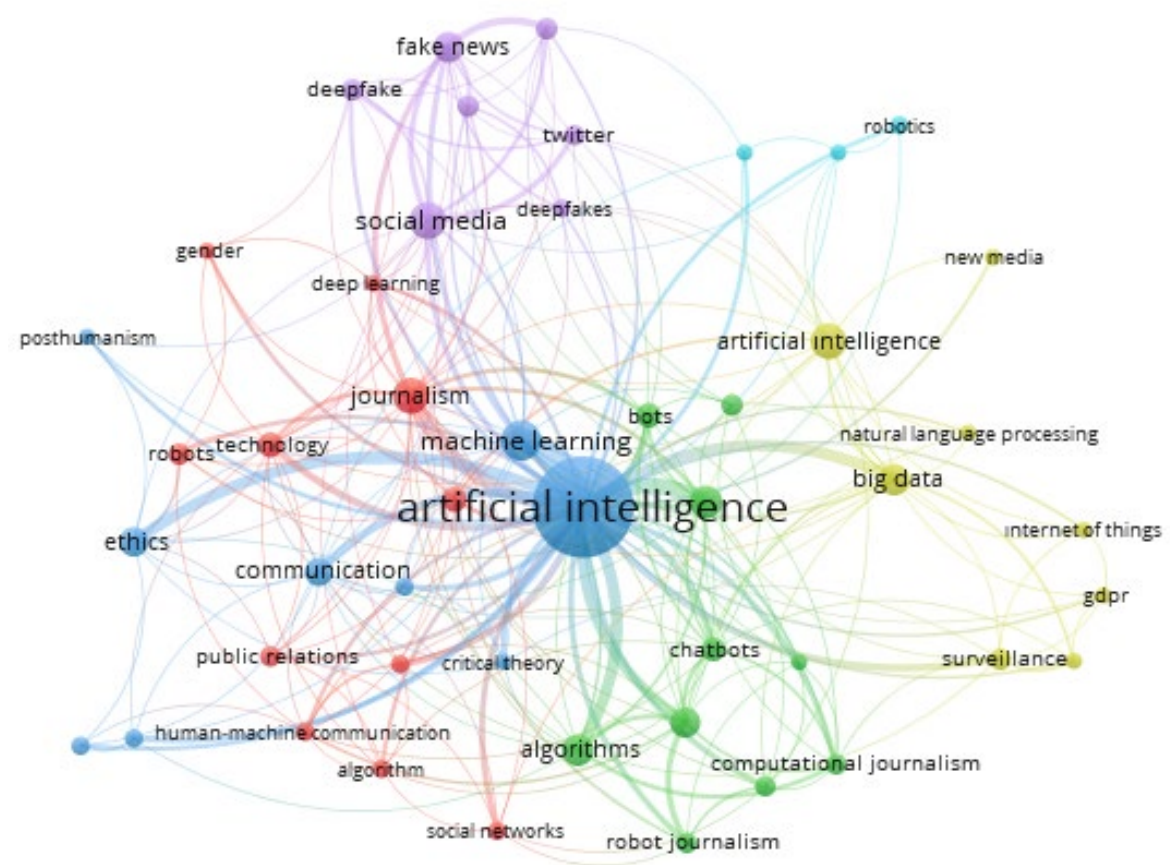

Figure 4 shows the words used together with artificial intelligence. It could be seen that the studies focused on journalism, natural language processing, human-robot interaction and public relations. "Automated journalism," "computational journalism," "robot journalism," "public relations," "human-machine communication," "chatbots," "social media," “ethics," "fake news," "deepfake," "posthumanism," "natural language processing" and "new media" were the main concepts in the studies.

\subsection{Citation Analysis}

In the citation analysis, two research questions were investigated. The first of these was to identify the most cited studies. Accordingly, the citation numbers of 459 studies were examined, and it was determined that these studies received 3,224 citations according to the Web of Science (WoS) records. The citation numbers in the WoS and Google Scholar records of the first ten studies are shown in Table 7. 
Table 7. Top 10 Most Cited Publications

\begin{tabular}{|c|c|c|c|c|}
\hline \multirow[b]{2}{*}{ Publication Name } & \multirow[b]{2}{*}{ Author(s) } & \multirow{2}{*}{$\begin{array}{l}\text { Publica- } \\
\text { tion Year }\end{array}$} & \multicolumn{2}{|c|}{ Number of Citations } \\
\hline & & & WoS & $\begin{array}{l}\text { Google } \\
\text { Scholar }\end{array}$ \\
\hline $\begin{array}{l}\text { The meaning of intonational } \\
\text { contours in the interpretation } \\
\text { of discourse }\end{array}$ & $\begin{array}{l}\text { Pierrehumbert, J; } \\
\text { Hirschberg, J }\end{array}$ & 1990 & 562 & 2,333 \\
\hline $\begin{array}{l}\text { Collective intentions and } \\
\text { actions }\end{array}$ & Searle, J. & 1990 & 377 & 1,635 \\
\hline Plans for discourse & $\begin{array}{l}\text { Grosz, BJ; } \\
\text { Sidner, CL }\end{array}$ & 1990 & 129 & 886 \\
\hline $\begin{array}{l}\text { Rational interaction as the } \\
\text { basis for communication }\end{array}$ & $\begin{array}{l}\text { Cohen, P.R; } \\
\text { Levesque, H.J }\end{array}$ & 1990 & 90 & 754 \\
\hline What is intention? & Bratman, ME & 1990 & 77 & 780 \\
\hline $\begin{array}{l}\text { Information manipulation } \\
\text { theory 2: A propositional } \\
\text { theory of deceptive discourse } \\
\text { production }\end{array}$ & $\begin{array}{l}\text { McCornack, } \\
\text { SA; Morrison, } \\
\text { K;Paik, JE;Wisner, } \\
\text { AM;Zhu, X }\end{array}$ & 2014 & 70 & 158 \\
\hline $\begin{array}{l}\text { Humanoid social robots as a } \\
\text { medium of communication }\end{array}$ & Zhao, SY & 2006 & 67 & 188 \\
\hline $\begin{array}{l}\text { Accommodation, meanıng, } \\
\text { and implicature - interdisci- } \\
\text { plinary foundations for prag- } \\
\text { matics }\end{array}$ & Thomason, RH & 1990 & 66 & 357 \\
\hline $\begin{array}{l}\text { Plans as complex mental at- } \\
\text { titudes }\end{array}$ & Pollack, ME & 1990 & 62 & 515 \\
\hline $\begin{array}{l}\text { RoboCup@Home scientific } \\
\text { competition and bench- } \\
\text { marking for domestic service } \\
\text { robots }\end{array}$ & $\begin{array}{l}\text { Wisspeintner, T; } \\
\text { van der Zant, T; } \\
\text { locchi, L; Schiffer,S }\end{array}$ & 2009 & 62 & 151 \\
\hline
\end{tabular}

Seven of the ten most-cited publications were presented at the Interdisciplinary Workshop on Intentions and Plans in Communication and Discourse conference held in California in 1987 and published by MIT Press in 1990. The topics covered in these papers were linguistic and natural language processing studies. Other publications were in the Journal of Language and Social Psychology in 2014, New Media \& Society in 2006, and Interaction Studies in 2009.

The second question was regarding the journals that were cited most frequently in the bibliographies of 459 articles. A total of 17,180 publications were cited in all of the studies. The top 15 most frequently cited journals are shown in Table 8. These journals made up about $10 \%$ of the total citations. 
Table 8. Journals Mostly Cited in Studies

\begin{tabular}{|r|l|r|r|}
\hline & Journal Name & $\mathbf{n}$ & $\mathbf{\%}$ \\
\hline 1 & Digital Journalism & 290 & 1.7 \\
2 & Computers in Human Behavior & 173 & 1.0 \\
3 & New Media \& Society & 150 & 0.9 \\
4 & Journal of Artificial Intelligence & 148 & 0.9 \\
5 & Journalism Practice & 115 & 0.7 \\
6 & Journal of Advertising & 103 & 0.6 \\
7 & Communications of the ACM & 83 & 0.5 \\
8 & Science & 75 & 0.4 \\
9 & Information, Communication \& Society & 70 & 0.4 \\
10 & Journal of Communication & 66 & 0.4 \\
11 & Journalism & 64 & 0.4 \\
12 & Public Relations Review & 63 & 0.4 \\
13 & Big Data \& Society & 61 & 0.4 \\
14 & Profesional de la información & 61 & 0.4 \\
15 & Journalism Studies & 55 & 0.2 \\
\hline & Total & 1,577 & 9.2 \\
\hline
\end{tabular}

In the distribution of journal citations, it was found that the most frequent reference was to Digital Journalism. Furthermore, while examining Table 8 , it could be seen that 5 of the eight core journals (Digital Journalism, New Media \& Society, Journal of Advertising, Information, Communication \& Society, Profesional de la información), which include the highest number o artificial intelligence studies, were ranked on this list. . The number of studies published in these journals and the number of citations determining the use of these studies reveal the importance of the abovementioned journals for meeting the literature needs.

Depending on citations made in the studies, the half-life value was calculated to determine the obsolescence of the literature. The years of the publications cited in 459 studies within the scope of the research varied between 1509 and 2021. The half-life value of the cited publications was seven years, namely, they were published in the last seven yearsThis shows that researchers on the subject follow the current literature and often refer to new publications. This value also demonstrates that publications on artificial intelligence quickly lose their actuality. 


\section{Conclusion}

This study aimed to determine the profile of artificial intelligence publications in communication and the trends related to the subject. For this purpose, communication studies on artificial intelligence published between 1982 and 2021 were examined. The distribution of citations in the bibliography of the studies examined within the scope of research according to scientific journals and the determination of the core journals meeting literature needs were among the sub-objectives of the research. The general structure of the literature was revealed by looking for answers to the predetermined research questions, and thus the most effective and most productive journals were presented.

The first publication on the subject was published in the Journal of Communication in 1982. After this date, one publication was made every year until 1990. 41 papers were presented at the artificial intelligence conferences held in communication in 1990 and 1993. Seven of the papers published in 1990 are among the top ten most cited studies. In this respect, the literature's foundations were laid in the congresses held in these years. A rapid increase in the number of publications began in 2016, and the number of publications reached 110 by 2020 . One reason why studies on human-machine interaction have accelerated since 2016 could be related to Facebook's introduction of chatbots in Messenger in 2016 and Microsoft's launch of the Twitter bot TAY in the same year.

$54.3 \%$ of the studies were multi-authored. When the author, institution, and country partnerships were examined, communication and collaborations among different disciplines became prominent. It was found that publication collaboration was established among 22 countries in total. England was the country that developed the most international partnerships by collaborating with 16 different countries. When it comes to the number of publications, the closest partnerships were established between the USA and England, Canada and Germany. The country that published the most was the USA, which constituted $25.1 \%$ of the literature. Turkey ranked 28th among 54 countries with four publications. Looking at these results, it can be said that the USA leaded the artificial intelligence studies in communication, and the studies in Turkey were quite limited in terms of contribution to the international literature. In the studies, 454 different universities were addressed. The institutions that contributed the most to the literature were universities in Spain, the USA, Netherlands, Canada and Malta.

Articles and papers constituted $81.3 \%$ of the studies. 96 different journals published 267 articles. It was found that the distribution of the articles in these journals was in accordance with Bradford's Law and that eight core journals covered 
the communication literature on artificial intelligence. 5 of these journals that published the most articles on the subject were most frequently cited in artificial intelligence articles. The coverage of the other most frequently cited journals was mostly in journalism, public relations, and advertising.

Based on the findings, the general focus areas were journalism, natural language processing, human-robot interaction, social media bots, public relations, and advertising. The concepts of automated journalism, computational journalism and robot journalism were used in articles focusing on artificial intelligence technologies. The most frequently used concepts such as ethics, fake news, and deepfake showed that ethical problems and fake content related to automated content production in journalism and advertising were examined.

When the publications in the bibliography of the studies were examined in the context of literature obsolescence, it was found that the half-life value of the cited publications was seven years. This result showed that references were made to publications that can be considered relatively new. In other words, researchers preferred to cite more recent studies. Therefore, in parallel with the speed of technological developments, it can be inferred that publications on artificial intelligence quickly lose their actuality and the communication literature on this subject has a very dynamic structure of change. These results would contribute to creating journal collections and subscriptions related to the field of communication in libraries.

The results showed that the use of artificial intelligence in the following subjects has become more widespread: automatic news production in journalism, social media management, competitor analysis, media monitoring, crisis communication, reputation management and advertising. Accordingly, the number of scientific studies on artificial intelligence in communication has increased. However, it was seen that the studies in Turkey were limited in terms of contribution to the international literature. Developments in artificial intelligence deeply affect the media and communication practices as well as individual and social life. This process of change should be explored dynamically through methodologies suitable for the information age. In addition, greater attention should be paid to partnerships that could be established with different disciplines. For example, partnerships should be established with researchers in engineering working on particular technologies such as deep learning, machine learning, and natural language processing, which are especially needed to analyze large data sets accumulated on the Internet and social media. Thus, rapid advances in these technologies should not be overlooked by communication researchers. 
The current research is limited to 459 studies published between 1982 and 2021. The fact that only the studies on artificial intelligence in communication were examined may be another limitation compared to the results obtained for the general communication literature. It is possible to follow the development of artificial intelligence studies and reach more detailed and comparative findings of the general structure of the communication field through further studies.

\section{Çıkar Çatışması Beyanı}

Makale yazarı herhangi bir çıkar çatışması olmadığını beyan etmiştir.

\section{References}

Akay, E. Ç., Soydan, T. Y., \& Gacar, B. K. (2020). Machine learning and economics: Bibliometric analysis. PressAcademia Procedia (PAP), 12, 104-109. doi:10.17261/ Pressacademia.2020.1367

Al, U., \& Tonta, Y. (2004). Atff analizi: Hacettepe Üniversitesi Kütüphanecilik Bölümü tezlerinde atf yapılan kaynaklar [Citation analysis: Sources cited in dissertations completed at Hacettepe University Department of Librarianship]. Information World/Bilgi Dünyası, 5(1), 19-47.

Alaimo, C., \& Kallinikos, J. (2018). Objects, metrics and practices: An inquiry into the programmatic advertising ecosystem. In U. Schultze, M. Aanestad, M. Mähring, C. Østerlund, \& K. Riemer (Eds.), Living with Monsters? Social Implications of Algorithmic Phenomena, Hybrid Agency, and the Performativity of Technology. IS\&O 2018. IFIP Advances in Information and Communication Technology (pp. 110-123). Springer, Cham. doi:10.1007/9783-030-04091-8_9

Binbaşığlu, H. (2020). Akıllı turizm üzerine bibliyometrik bir literatür taraması [A bibliometric literature review on smart tourism]. Journal of Tourism and Gastronomy Studies, 8(4), 2825-2847. doi:10.21325/jotags.2020.740

Busch, O. (2016). The programmatic advertising principle. In O. Busch (Ed.), Programmatic Advertising (pp. 3-15). Springer, Cham. doi:10.1007/978-3-319-25023-6_1

Calvo Rubio, L. M., \& Ufarte Ruiz, M. J. (2021). Artificial intelligence and journalism: Systematic review of scientific production in Web of Science and Scopus (2008-2019). Communication \& Society, 34(2), 159-176.

Caswell, D., \& Dörr, K. (2018). Automated journalism 2.0: Event-driven narratives. Journalism Practice, 12(4), s. 477-496. doi:10.1080/17512786.2017.1320773

Egghe, L., \& Rousseau, R. (1990). Introduction to informetrics: Quantitative methods in library, documentation and information science. Amsterdam: Elsevier. Retrieved from https://documentserver.uhasselt.be//handle/1942/587

Garfield, E. (1980). Bradford's law and related statistical patterns. Essays of an Information Scientist, 4, 476-483. Retrieved from http://garfield.library.upenn. edu/essays/v4p476y1979-80.pdf 
Gökkurt, Ö. (1994). Enformetri, Bradford Yasası ve citation indeks [Informetrics, Bradford's Law and citation index]. Turkish Librarianship/Türk Kütüphaneciliği, 8(1), 26-30.

Kocakoç, İ. D., Kantarcı, S., İyilikçi, V., \& Başok, B. İ. (2021). COVID-19 ile ilişikili yapay zekâ araştırmalarının veri bilimi yöntemleriyle bibliyometrik analizi [Bibliometric analysis of artificial intelligence studies related to COVID-19 using data science methodologies]. II. International Artificial Intelligence Health Congress, Artificial Intelligence: Theory and Applications. Special Issue (Abstracts), s. 57. Izmir: Izmir Bakircay University. Retrieved from https:// aita.bakircay.edu.tr

Lee, N., Kim, K., \& Taeseon, Y. (2017). Implementation of robot journalism by programming custombot using tokenization and custom tagging. 19th International Conference on Advanced Communication Technology (ICACT) (pp. 566570). PyeongChang: IEEE. doi:10.23919/ICACT.2017.7890154

McGuigan, L. (2019). Automating the audience commodity: The unacknowledged ancestry of programmatic advertising. New Media \& Society, 21(11-12), 23662385. doi:10.1177/1461444819846449

Nash-Stewart, C. E., Kruesi, L. M., \& Del Mar, C. B. (2012). Does Bradford's Law of Scattering predict the size of the literature in Cochrane Reviews? Journal of the Medical Library Association, 100(2), 135-138. doi:10.3163/15365050.100.2.013

Özdemir, M., \& Selçuk, S. A. (2021). Mimarlıkta makine öğrenmesi: Bibliyometrik bir analiz [Machine learning in architecture: A bibliometric analysis]. Online Journal of Art and Design, 9(4), 194-207.

Özel, Ç. H., \& Kozak, N. (2012). Turizm Pazarlaması Alanının Bibliyometrik Profili (20002010) ve Bir Atf Analizi Çalışması [Bibliometric profile of tourism marketing literature from 2000 to 2010 and a citation analysis study]. Turkish Librarianship/Türk Kütüphaneciliği, 26(4), 715-733.

Pritchard, A. (1969). Statistical bibliography or bibliometrics? Journal of Documentation, 25(4), 348-349.

Schwencke, K. (2021). GitHub. Retrieved July 4, 2021, from https://github.com/schwanksta

Sim, D. H., \& Shin, S. J. (2016). Implementation of algorithm to write articles by Stock Robot. International Journal of Advanced Smart Convergence, 5(4), 40-47. doi:10.7236/IJASC.2016.5.4.40

Tosyalı, H., \& Aytekin, Ç. (2020). Development of Robot Journalism Application: Tweets of News Content in the Turkish Language Shared by a Bot. Journal of Information Technology Management, 12(Special Issue), 68-88. doi:10.22059/ JITM.2020.79335

White, G. R., \& Samuel, A. (2019). Programmatic advertising: Forewarning and avoiding hype-cycle failure. Technological Forecasting and Social Change, 144, 157168. doi:10.1016/j.techfore.2019.03.020 


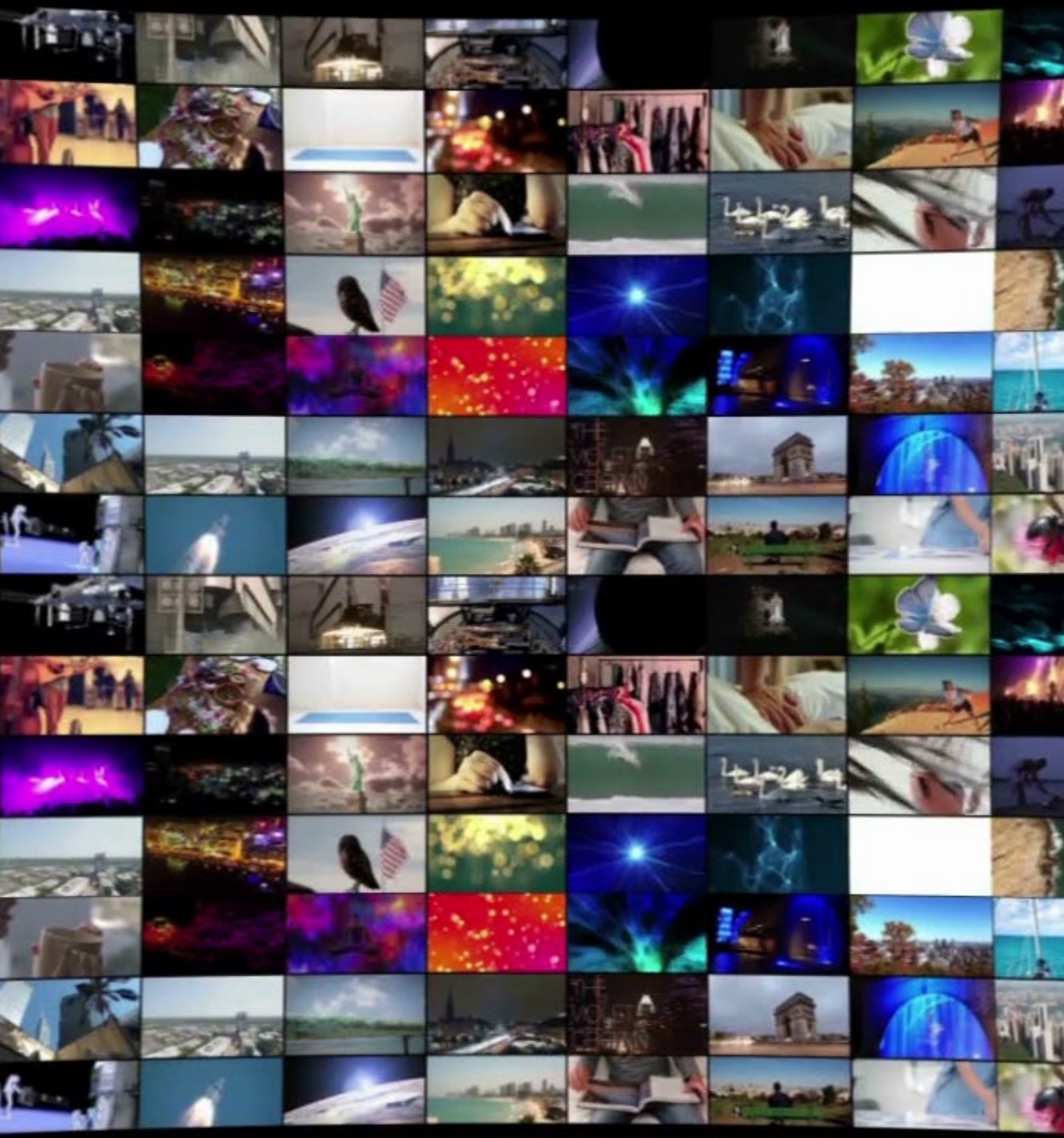

